\title{
Treatment of landfill leachates with biological pretreatments and reverse osmosis
}

\author{
Izabela Anna Tałałaj ${ }^{1}\left[\right.$ D Paweł Biedka ${ }^{1}$. Izabela Bartkowska ${ }^{1}$
}

Received: 10 November 2018 / Accepted: 31 January 2019 / Published online: 11 February 2019

(c) The Author(s) 2019

\begin{abstract}
Landfill leachates from municipal landfills are usually heavily contaminated and thus require treatments before direct discharge into natural waters. Selecting the appropriate technology for leachate treatment is still a major challenge for operations in municipal landfills. Biodegradation is effective for treating young leachates, whereas old leachates require processes such as chemical oxidation, coagulation-flocculation, chemical precipitation, ozonation, activated carbon adsorption, and reverse osmosis. Recently, the combination of biological pretreatments followed by physico-chemical processes has been shown to be very efficient. Here we review the efficiency of biological treatment in combination with reverse osmosis to clean landfill leachates. We studied in particular processes including a membrane bioreactor, activated sludge, a rotating biological contactor, and up-flow anaerobic sludge blanket treatments, followed by reverse osmosis. We found a 99-99.5\% removal of the chemical oxygen demand (COD), and a $99-99.8 \%$ removal of $\mathrm{N}_{-} \mathrm{NH}_{4}{ }^{+}$using reverse osmosis and activated sludge. Using reverse osmosis with a rotating biological contactor, we observed $99 \%$ removal of COD, biochemical oxygen demand and $\mathrm{N}-\mathrm{NH}_{4}{ }_{4}$. The combination of reverse osmosis, activated sludge and rotating biological contactor removed $98-99.2 \%$ of $\mathrm{Cl}^{-}$and $99-99.7 \%$ of $\mathrm{Pb}$. Total suspended solids are best removed, up to 99\%, by either a combination of reverse osmosis with membrane bioreactor, or reverse osmosis with activated sludge.
\end{abstract}

Keywords Biological pretreatment $\cdot$ Landfill $\cdot$ Leachate $\cdot$ Removal effect $\cdot$ Reverse osmosis

\section{Introduction}

A major issue arising from solid waste landfilling is the generation of landfill leachates. Leachates are high-strength wastewaters formed as a result of percolation of rainwater and moisture through waste in landfills (Hasar et al. 2009). Leachates contain a mixture of organic and inorganic contaminants including humic acids, ammonia nitrogen, heavy metals, xenobiotics, and inorganic salts, and its composition depends upon the landfill age, the quality and quantity of waste, biological and chemical processes that took place during disposal, rainfall density, and water percolation rate through the waste in landfill (Pasalari et al. 2018; Hasar et al. 2009; Wiszniowski et al. 2006).

Izabela Anna Tałałaj

izabela.tj@gmail.com

1 Department of Technology and Environmental Engineering Systems, Bialystok University of Technology, Wiejska 45A Street, 15-351 Bialystok, Poland
With time leachate goes through the successive aerobic, acetogenic, methanogenic, and stabilization stages of organic waste degradation, in which its properties such as chemical oxygen demand, biological oxygen demand, BOD/COD ratio, ammonium nitrogen, and $\mathrm{pH}$ vary widely (Ahmed and Lan 2012; Kjeldsen et al. 2002). These parameters have their typical ranges depending on leachate/landfill age, which is commonly classified into three stages: young (lower than 5 years), medium/intermediate (5-10 years), and old/stabilized (more than 10 years) (Table 1) (Kurniawan et al. 2006; Alvarez-Vazquez et al. 2004; Ahmed and Lan 2012; Foo and Hameed 2009).

Leachate produced in young landfills is characterized by the high (more than 0.5) BOD/COD ratio, which is used as a measure of leachate biodegradability. Therefore, the BOD/COD ratio decreases with time because the non-biodegradable portion of COD will largely stay unchanged in this process (Ahmed and Lan 2012). Principal pollutant in leachate is also ammonia nitrogen. Ammonia nitrogen is present in leachate in young landfills owing to the deamination of amino acids during destruction of organic compounds 
Table 1 Characterization of landfill leachate with age

\begin{tabular}{|c|c|c|c|}
\hline Parameter & Young & Intermediate & Stabilized \\
\hline Age (years) & $<5(<1)^{*}$ & $5-10(1-5)^{*}$ & $>10(>5)^{*}$ \\
\hline $\mathrm{pH}$ & $<6.5$ & $6.5-7.5$ & $>7.5$ \\
\hline $\mathrm{BOD} / \mathrm{COD}$ & $0.5-1$ & $0.1-0.5$ & $<0.1$ \\
\hline $\begin{array}{l}\text { Chemical oxygen } \\
\text { demand (COD) } \\
(\mathrm{mg} / \mathrm{L})\end{array}$ & $>15,000$ & $4-15,000$ & $<4000$ \\
\hline $\mathrm{NH}_{3}-\mathrm{N}(\mathrm{mg} / \mathrm{L})$ & $<400$ & - & $>400$ \\
\hline $\begin{array}{l}\text { Total organic carbon } \\
\text { (TOC)/COD }\end{array}$ & $<0.3$ & $0.3-0.5$ & $>0.5$ \\
\hline $\begin{array}{l}\text { Total Kjeldahl nitrogen } \\
(\mathrm{TKN})(\mathrm{g} / \mathrm{L})\end{array}$ & $0.1-2$ & - & - \\
\hline Heavy metals (mg/L) & $>2$ & $<2$ & $<2$ \\
\hline Biodegradability & High & Medium & Low \\
\hline
\end{tabular}

Quality of leachate from young landfills differs from stabilized leachate. For young leachate a high concentration of organics, low $\mathrm{pH}$ value, and higher BOD/COD ratio are observed in contrast to the low biodegradation of stabilized leachate, their higher $\mathrm{pH}$ value, and lower ratio of $\mathrm{BOD} / \mathrm{COD}$

TOC total organic carbon, TKN total Kjeldahl nitrogen

*Value according to Kurniawan et al. (2006)

(Kulikowska and Klimiuk 2008; Tatsi and Zouboulis 2002). Leachate from older landfill is rich in ammonia nitrogen due to hydrolysis and fermentation of the nitrogenous fraction of biodegradable substrates. The variation of organics and ammonia nitrogen with time may have important implications in leachate treatment. Regardless of landfill age, leachate contains many types of contaminants, which may be toxic to life or simply alter the ecology of receiving streams. It can accelerate algae growth due to its high nutrient content, deplete dissolved oxygen in the water, and cause toxic effect in the surrounding water life (Hasar et al. 2009).

Owing to the potential risk posed by the heavily polluted leachate, it should meet stricter quality standards regarding the direct discharge of leachate (or any wastewater) (Zolfaghari et al. 2017). To meet these stricter quality standards, on-site treatment of leachate becomes imperative and the selection of an appropriate technology more so (Ahmed and Lan 2012). Treatment technology for leachate, as well for wastewater, should be considered seriously after fully understanding its composition and concentration (Crini and Lichtfouse 2018). Biological treatments such as conventional activated sludge, aerated lagoons, sequencing batch reactors, up-flow anaerobic sludge blanket, membrane bioreactors, and rotating biological contactors are widely and effectively employed for treating young leachate with high BOD concentration (Kurniawan et al. 2006; Ahmed and Lan 2012).

It was found that the most studied aerobic processes for leachate treatment in the world are aerobic lagoons-21\%, upflow anaerobic sludge blanket-18\%, activated sludge $-17 \%$, and sequencing batch reactors- $15 \%$. The membrane bioreactor accounts for $8 \%$ (Hasar et al. 2009). These methods are probably the most efficient and cheapest process to eliminate nitrogen from leachate (Wiszniowski et al. 2006). However, biological treatment is hampered by the specific toxic substances and/or the presence of bio-refractory organics. That is why the COD removal from old leachate presents a problem for these conventional biological treatments. For such a leachate the physical and chemical processes including chemical oxidation, coagulation-flocculation, chemical precipitation, ozonation, activated carbon adsorption, and reverse osmosis should be considered. Among these processes reverse osmosis has been one of the most widely used methods for the last years. This development is due to the ability to retain inorganic and organic contaminations dissolved in leachate with high efficiency (Trebouet et al. 2001; Theepharaksapan et al. 2011). Chianese et al. (1999) reported, that the rejection coefficients for COD parameter and heavy metals concentration were higher than 0.98 and 0.99 , respectively.

The disadvantage of treating leachate with reverse osmosis is membrane fouling, which decreases the treatment effectiveness and concentrate production, which is difficult to manage. Moreover, during reverse osmosis the separation of ammonium is often not sufficient. Therefore, a number of scientists around the world have intensively focused on the combination of biological and physico-chemical treatment systems for effective leachate treatment. A potential process in the treatment is biological pretreatment of leachate followed by reverse osmosis purification. Biological pretreatment is able to reduce the organic constituents that either contribute directly to organic fouling or provide carbon sources for the development of biofilms on the membrane surface (Wend et al. 2003). Integration of biological and reverse osmosis processes can yield a high reduction rate of COD, ammonium nitrogen, and heavy metals.

Numerous research studies on the treatment of leachate using biological (Geradi 2002; Alvarez-Vazquez et al. 2004; Sponza and Ağdağ 2004; Uygur and Kargi 2004; Kim et al. 2005; Parkes et al. 2007; Wiszniowski et al. 2006; Zhang et al. 2007; Kamaruddin et al. 2013) and reverse osmosis (Dydo et al. 2005; Robinson 2005; Liu et al. 2008; Li et al. 2009; Ushikoshi et al. 2002; Renou et al. 2008; Richards et al. 2010; Theepharaksapan et al. 2011) methods have been carried out worldwide in recent years. However, there are hardly any review papers that provide a comprehensive overview of efficiency of combination different biological pretreatment methods with reverse osmosis. To cover this gap this paper aims to evaluate the effectiveness of reverse osmosis system with different biological pretreatments. 


\section{Effectiveness of reverse osmosis with different biological leachate pretreatments}

\section{Membrane bioreactor and reverse osmosis}

Membrane bioreactor is the combination of a membrane process like microfiltration or ultrafiltration with a suspended growth bioreactor (Judd 2006). So, it is essentially composed of two primary parts: the biological unit or bioreactor responsible for the biodegradation of waste compounds and the membrane module for the separation of treated water from biosolids or microorganisms (Cicek 2003; Ahmed and Lan 2012). It leads to increased microorganisms concentration in reactor and improvement in process efficiency with lower sludge production.

Membrane bioreactor allows for complete retention of biomass, enabling membrane bioreactor to operate with significantly higher mixed liquor suspended solids concentration (10-20 g/L) and produce higher-quality effluents (Patsios and Karabelas 2011). Moreover, it does not require space for sedimentation tanks; therefore, it is a good option in case of limited land area (Pearce 2008; Akgul et al. 2013). There are two types of membrane bioreactors according to the locations of membrane units, i.e. submerged (internal) and external (sidestream) reactors (Fig. 1) (Bohdziewicz et al. 2008).

In submerged membrane bioreactor the membrane module is installed inside the reactor. The membranes can be flat sheet or tubular or combination of both (Wang et al. 2008). In the sidestream configuration, the membrane is outside the reactor and the sludge is recirculated to the aeration tank. Sufficiently high cross-flow velocities need to be maintained in a sidestream membrane bioreactor to overcome flux decline due to fouling. The absence of a high-flow recirculation pump in a submerged membrane

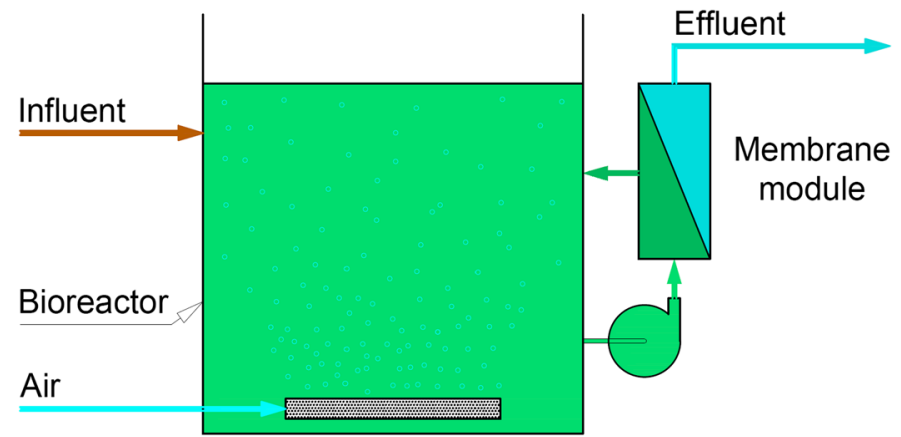

Fig. 1 Membrane bioreactor configurations. A membrane bioreactor is a combination of a biological leachate/wastewater treatment process with a membrane process such as microfiltration or ultrafiltration. Two configurations of membrane bioreactor exist: external (left), bioreactor results in a more compact, low-cost, and energy-saving system (Ahmed and Lan 2012). In spite of the advantages offered by the submerged configuration, external systems are generally considered to be more suitable for wastewater with high temperature, $\mathrm{pH}$, organic strength, toxicity, and fouling tendencies. Since membrane filtration in an external membrane bioreactor is usually operated in the cross-flow mode as opposed to the deadend mode of submerged systems, membrane fouling is less of a problem in external systems. Given the high fouling potential and low filterability of leachate, the majority of the membrane bioreactor systems utilized for landfill leachate treatment are based on external systems system (Ahmed and Lan 2012).

The main advantage of the membrane bioreactor process is that it reduces the importance for biomass sedimentation, thus allowing a significantly smaller tank to be used for the bio-treatment process. The second main advantage of a membrane bioreactor is that the treated water quality is better than from a conventional process, since the membrane barrier removes essentially all particulates above the pore size rating of the membrane (Pearce 2008). The efficiency of membrane bioreactor according to different research studies is presented in Table 2 .

The effluent from membrane bioreactors treating landfill leachate is characterized by low BOD/COD ratio (lower than 0.1 ) indicating the presence of refractory organic matter. The membrane bioreactor achieved more than $98 \%$ of BOD removal. However, high COD concentration was still found in effluents of membrane bioreactors due to a certain amount of refractory compounds present in landfill leachate. The removal rate of $\mathrm{N}-\mathrm{NH}_{4}{ }^{+}$was from 60 to $80 \%$; the removal rate of total Kjeldahl nitrogen was slightly higher and ranged from 60 to $97 \%$.

The membrane bioreactor filtration performance inevitably decreases with filtration time. This is due to the deposition of soluble and particulate materials onto and into the

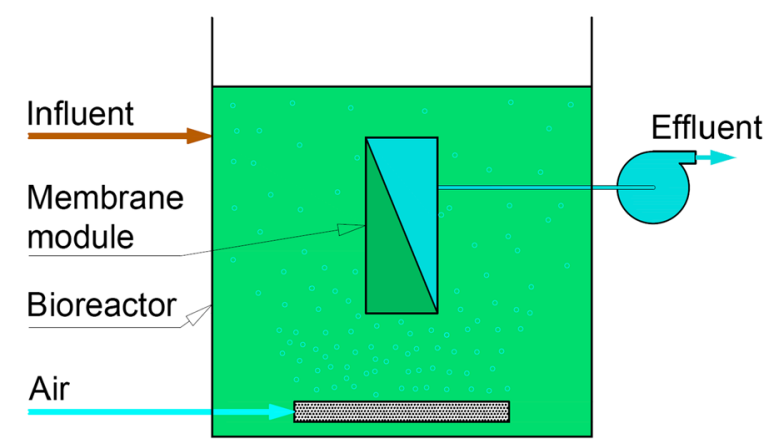

where membranes are a separate unit requiring intermediate pumping step, and submerged (right), where the membranes are immersed in and integral to the biological reactor. Source: Adapted from Ng and Kim (2007) 
Table 2 Performance of membrane bioreactors for treating landfill leachates

\begin{tabular}{|c|c|c|c|c|c|c|}
\hline Parameter & Influent (mg/L) & $\mathrm{BOD} / \mathrm{COD}$ & $\begin{array}{l}\text { MBR effluent } \\
(\mathrm{mg} / \mathrm{L})\end{array}$ & Removal (\%) & Type & References \\
\hline COD & $400-1500$ & $\approx 0.3$ & $211-856$ & - & Full scale & Ahn et al. (2001) \\
\hline BOD & $100-500$ & & $4.3-29$ & - & & \\
\hline $\mathrm{N}-\mathrm{NH}_{4}^{+}$ & $200-1400$ & & $100-408$ & - & & \\
\hline $\mathrm{COD}$ & 1800 & 0.15 & - & 31.3 & Laboratory scale & Setiadi and Fairus (2003) \\
\hline BOD & 267.5 & & - & 98 & HRT: $24 \mathrm{~h}$ & \\
\hline $\mathrm{N}-\mathrm{NH}_{4}{ }^{+}$ & 114.8 & & - & 66 & & \\
\hline BOD & - & n.a. & $10-500$ & $75-99$ & Laboratory scale & Akgul et al. (2013) \\
\hline COD & 442 & 0.65 & - & 82.4 & Laboratory scale & Bodzek et al. (2006) \\
\hline BOD & 290 & & - & 98.3 & & \\
\hline TOC & 127 & & - & 74.7 & & \\
\hline TKN & $230-1960$ & n.a. & - & $80-97$ & Full scale & Chiemchaisri et al. (2011) \\
\hline COD & - & n.a. & - & $60-80$ & Full scale & Visvanathan et al. (2007) \\
\hline BOD & - & & - & $90-97$ & HRT: $24 \mathrm{~h}$ & \\
\hline $\mathrm{N}-\mathrm{NH}_{4}{ }^{+}$ & - & & - & $60-80$ & & \\
\hline TKN & $1300-1900$ & & - & $60-75$ & & \\
\hline
\end{tabular}

Membrane bioreactor performance was characterized by higher efficiency of BOD removal than of COD removal. The removal rates for N$\mathrm{NH}_{4}{ }^{+}$and total Kjeldahl nitrogen were similar and ranged from 60 to about $90 \%$

$M B R$ membrane bioreactor, TOC total organic carbon, $T K N$ total Kjeldahl nitrogen, HRT hydraulic retention time, n.a. data not available

membrane, attributed to the interactions between activated sludge components and the membrane (Cui et al. 2003). Membrane fouling has been identified as the main disadvantage of operation of membrane bioreactors just as high membrane cost and high energy consumption.

Membrane bioreactor may provide excellent pretreatment for subsequent reverse osmosis stages. If dissolved substances need to be removed by reverse osmosis, membrane filtration is essentially mandatory as a pretreatment to reverse osmosis in order to achieve stable performance. Table 3 presents the effectiveness of reverse osmosis with membrane bioreactor pretreatment in purification of landfill leachate.

As can be seen from Tables 2 and 3, successful landfill leachate treatment using membrane bioreactor process requires the integration of additional physico-chemical stages such as reverse osmosis.

The treatment of leachate from landfill in Chung Nam Province (Korea) using a combination of membrane bioreactor and reverse osmosis unit was examined by Ahn et al. (2001). As presented in Table 3, the average removal rate of BOD in membrane bioreactor was $96 \%$ and then pretreatment water was transferred to reverse osmosis, with final removal rate of $97 \%$. N- $\mathrm{NH}_{4}{ }^{+}$removal after membrane bioreactor stage was $50-70 \%$ and increased to $96 \%$ after reverse osmosis treatment. In case of $\mathrm{N}^{-\mathrm{NO}_{3}}{ }^{-}$the final removal effect was $93 \%$ and most of nitrate was removed during reverse osmosis process. This is due to the fact that generally negatively charged reverse osmosis membranes remove negatively charged nitrate and nitrite better than positively charged ammonium ion or neutral ammonia (Ahn et al. 2001). Membrane bioreactor also performed an effective pretreatment for reverse osmosis membranes by removing total suspended solids by over $99 \%$, which prevents clogging of reverse osmosis membrane. The overall COD removal rate was $97 \%$. Only about $40 \%$ was removed by membrane bioreactor, and the rest about $60 \%$ was removed by reverse osmosis.

A combination of membrane bioreactor and reverse osmosis was studied for the treatment of stabilized leachate from Sobuczyna (Poland). The COD removal efficiency achieved a value of $99 \%$. Effluent COD after membrane bioreactor process decreases from $5000 \mathrm{mg} / \mathrm{L}$ to the value of $417 \mathrm{mg} / \mathrm{L}$, and after reverse osmosis process to the $12 \mathrm{mg} / \mathrm{L}$. A slightly lower level of leachate purification was achieved in the case of $\mathrm{N}-\mathrm{NH}_{4}{ }^{+}$. A poor-quality effluent with $206 \mathrm{mg} / \mathrm{L} \mathrm{N}-\mathrm{NH}_{4}{ }^{+}$ was directed to reverse osmosis module. The post-treatment reverse osmosis process allows to achieve the efficiency of $92 \%$ in $\mathrm{N}-\mathrm{NH}_{4}{ }^{+}$removal.

A two-stage treatment of young/intermediate (BOD/ COD: 0.4-0.7) leachate from Diyarbakir landfill (Turkey) consisting of membrane bioreactor and reverse osmosis was undertaken by Hasar et al. (2009). About 99\% COD removal was achieved with the initial concentration of $7300 \mathrm{mg} / \mathrm{L}$. This result is in agreement with those of previous studies carried out by Ahn et al. (2001) and Bohdziewicz et al. (2008). A combination of biological and physico-chemical treatments reduced the conductivity 
Table 3 Effectiveness of reverse osmosis with membrane bioreactor pretreatment for purification of landfill leachate

\begin{tabular}{|c|c|c|c|c|c|c|c|c|}
\hline Parameter & Influent & $\mathrm{BOD} / \mathrm{COD}$ & MBR effluent & RO effluent & Removal & Type & Localization & References \\
\hline BOD & $100-500$ & \multirow[t]{5}{*}{$0.25-0.33$} & $4.3-29$ & $1-7$ & 97 & MBR: submerged & Korea & \multirow{5}{*}{ Ahn et al. (2001) } \\
\hline COD & $400-1500$ & & $211-856$ & $6-72$ & 97 & \multirow{4}{*}{$\begin{array}{l}\text { RO: spiral wound } \\
\text { module type, } \\
\text { polyamide mem- } \\
\text { brane } 6.7 \mathrm{~m}^{2} \\
\text { sodium rejection } \\
99 \%\end{array}$} & Chung Nam & \\
\hline TSS & $200-1000$ & & $1-5$ & $1-1.6$ & 99 & & Province & \\
\hline $\mathrm{N}-\mathrm{NH}_{4}^{+}$ & $200-1400$ & & $100-408$ & $10-47$ & 96 & & \multirow[t]{2}{*}{ Full scale } & \\
\hline $\mathrm{N}-\mathrm{NO}_{3}{ }^{-}$ & $28-251$ & & $34-378$ & $7-23$ & 93 & & & \\
\hline COD & 5000 & $\begin{array}{c}\text { Low ratio (stabi- } \\
\text { lized leachate) }\end{array}$ & 417 & 12 & 99 & MBR: submerged & Poland & $\begin{array}{l}\text { Bohdziewicz et al. } \\
\text { (2008) }\end{array}$ \\
\hline $\mathrm{pH}$ & 8.03 & & 8.18 & 8.9 & n.a. & \multirow[b]{2}{*}{$\begin{array}{l}\text { RO: pressure } \\
\text { 4.0 MPa poly- } \\
\text { amide membrane } \\
\text { sodium rejection } \\
98.9 \%\end{array}$} & Sobuczyna & \\
\hline $\mathrm{N}-\mathrm{NH}_{4}^{+}$ & 381.5 & & 206 & 29.8 & 92 & & Laboratory scale & \\
\hline COD & 7300 & \multirow[t]{4}{*}{$0.4-0.7$} & 450 & 3.4 & 99 & MBR: submerged & Turkey & Hasar et al. (2009) \\
\hline $\mathrm{N}-\mathrm{NO}_{2}^{-}$ & 0.8 & & 0.2 & n.a. & n.a. & $\begin{array}{l}\text { RO: pressure } 2.758 \\
\text { kPA }\end{array}$ & Diyarbakir & \\
\hline $\mathrm{N}-\mathrm{NO}_{3}^{-}$ & $5-47$ & & $0.5-8.0$ & n.a. & n.a. & \multirow{3}{*}{$\begin{array}{l}\text { Thin-film mem- } \\
\text { brane } 3.79 \mathrm{~m}^{2} \\
\text { sodium rejection } \\
99.4 \%\end{array}$} & \multirow[t]{2}{*}{ Laboratory scale } & \\
\hline $\mathrm{N}-\mathrm{NH}_{4}^{+}$ & $200-600$ & & 15 & n.a. & n.a. & & & \\
\hline $\mathrm{EC}$ & 7.4 & & n.a. & 0.02 & $>99$ & & & \\
\hline COD & $400-500$ & $\begin{array}{c}\text { Low ratio (stabi- } \\
\text { lized leachate) }\end{array}$ & n.a. & n.a. & 97 & n.a. & South Korea & $\begin{array}{l}\text { Ahmed and Lan } \\
\text { (2012) }\end{array}$ \\
\hline $\mathrm{N}-\mathrm{NH}_{4}^{+}$ & $200-1400$ & & n.a. & n.a. & 96 & & Full scale & \\
\hline
\end{tabular}

A combination of membrane bioreactor with reverse osmosis was characterized by over 97\% BOD and COD removal. The use of reverse osmosis as a second step of leachate treatment improves the efficiency of nitrogen compounds $\left(\mathrm{N}-\mathrm{NH}_{4}{ }^{+}, \mathrm{N}-\mathrm{NO}_{3}{ }^{-}\right)$removal

Values of influent and effluent in $\mathrm{mg} / \mathrm{L}$ except for $\mathrm{pH}$ and $\mathrm{EC}(\mathrm{mS})$, removal effect in \%

$R O$ reverse osmosis, $M B R$ membrane bioreactor, TSS total suspended solids, $E C$ electroconductivity, n.a. data not available

of treated leachate from 7.4 to $0.02 \mathrm{mS}$ giving over $99 \%$ removal effect. There is no clear value of removal effect for $\mathrm{N}-\mathrm{NH}_{4}{ }^{+}$compound in Hasar et al. (2009) investigation. Nevertheless, they suggest that reverse osmosis is technically applicable and appealing for the treatment of stabilized leachate.

A comparative study of the treatment of leachate by using combination of membrane bioreactor and different physico-chemical processes was evaluated by Ahmed and Lan (2012). Authors point out a high removal of both COD (97\%) and $\mathrm{N}-\mathrm{NH}_{4}{ }^{+}(96 \%)$ from old leachate with the use of a two-stage process that integrates a membrane bioreactor unit with a post-treatment reverse osmosis module. Membrane bioreactor in this case is responsible for removing the bulk of the influent $\mathrm{N}-\mathrm{NH}_{4}{ }^{+}$and BOD and producing an effluent completely devoid of suspended solids, which aids in mitigating clogging and fouling problems commonly faced by downstream membrane processes (Ahmed and Lan 2012). The results suggest that a combination of membrane bioreactor and reverse osmosis treatment was able to optimize the removal of recalcitrant compounds and ammonia from landfill.

\section{Activated sludge and reverse osmosis}

The activated sludge is a process which involves air or oxygen being introduced into a mixture of screened and primary treated wastewater (leachate) combined with organisms to develop a biological floc which reduces the organic content of the sewage. The microorganisms consume the organic matter and transform it by means of aerobic metabolism, partly into new microbial biomass and partly into carbon dioxide, water, and minerals (Wiszniowski et al. 2006). The combination of wastewater and biological mass is commonly known as mixed liquor. In all activated sludge plants, once the wastewater has received sufficient treatment, excess mixed liquor is discharged into settling tanks and the treated supernatant is run off to undergo further treatment before discharge. Part of the settled material, the sludge, is returned to the head of the aeration system to re-seed the new influent entering the tank. The surplus amount is discharged (Fig. 2).

The reactions occurring in the activated sludge process can be summarized as follows (Wiszniowski et al. 2006): 


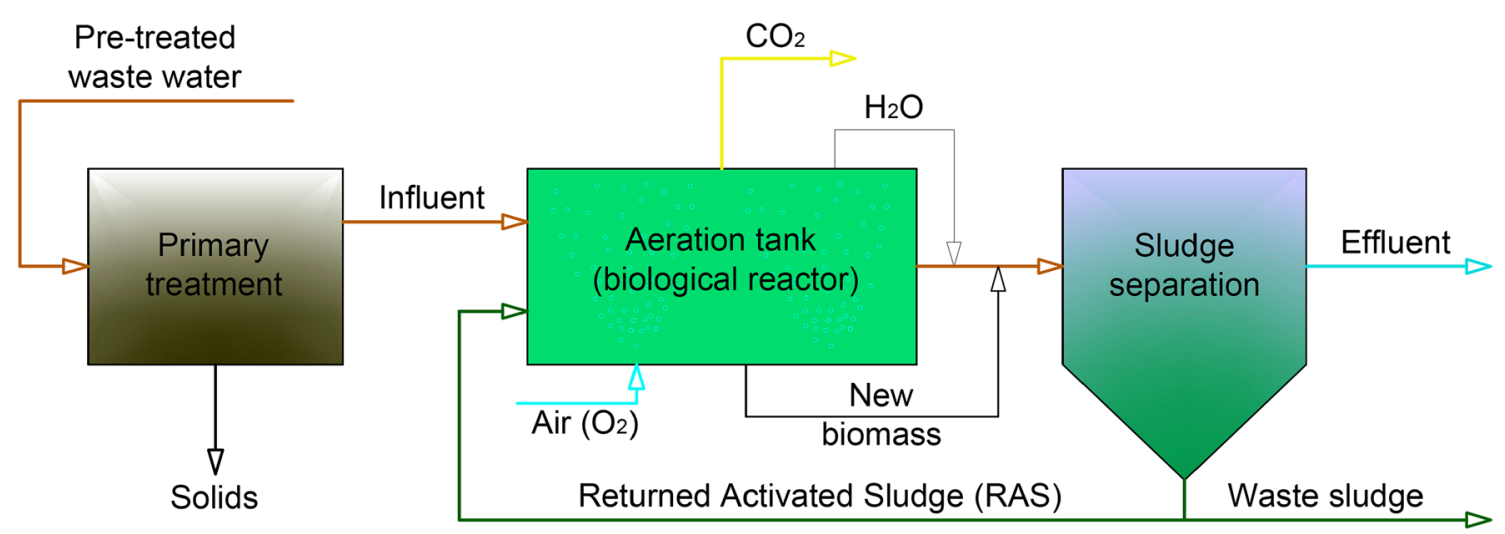

Fig. 2 Wastewater treatment by aeration and activated sludge. The settled leachate from primary treatment tank is directed to aeration tank where air (or oxygen) is injected in the mixed liquor. In aeration tank leachate is also mixed with required amount of activated sludge coming from sludge separation tank. The biological

1. Sorption of soluble, colloidal, and suspended organics in and on the sludge flocs.

2. Biodegradation (oxidation) of the organics resulting in the end products $\left(\mathrm{CO}_{2}, \mathrm{H}_{2} \mathrm{O}\right.$ and minerals $)$ and synthesis of new microbial biomass according to equation:

$\underset{\text { Organic-matter }}{\mathrm{CHONS}}+\mathrm{O}_{2}+$ Nutrients $\rightarrow \mathrm{CO}_{2}+\mathrm{NH}_{3}+\underset{\text { New-bacterial-cells }}{\mathrm{C}_{5} \mathrm{H}_{7} \mathrm{NO}_{2}}$

In aerobic treatment about half of the organic carbon is assimilated into the biomass, while the other half is respired to form $\mathrm{CO}_{2}$.

3. Ingestion of bacteria and possibly of other suspended matter by protozoa or other predators.

4. Oxidation of ammonium to nitrite and further to nitrate by the nitrifying bacteria.

5. In moments of insufficient supply of energy (leachate), oxidation of cell reserves (internal and also external) resulting in sludge mineralization takes place.

The important process in leachate treatment is nitrogen removal, whose concentration increases with landfill age. Old leachate has inhibition effect on activated sludge due to their high ammonium concentration. However, the phosphorus deficiency hampers the production of microorganisms and consequently the treatment performance (Chaundhari et al. 2008).

Three major biological processes directly involved in biological nitrogen removal in wastewater treatment are: ammonification, nitrification/denitrification, and anammox. Ammonification occurs when organic nitrogen is converted to ammonia. It is an important mechanism that allows organic nitrogen to be removed from wastewaters. process in aeration tank takes advantage of aerobic microorganisms that can digest organic matter in sewage and clump together creating flocs. Sludge separation tank allows the biological flocs to settle, thus separating the biological sludge from the clear treated water. Source: adapted from Kiely 1997

In nitrification process the oxidation of ammonium is performed by bacteria such as the Nitrosomonas species, which converts ammonia to nitrites $\left(\mathrm{NO}_{2}^{-}\right)$. Then, other bacterial species, such as the Nitrobacter, are responsible for the oxidation of the nitrites into nitrates $\left(\mathrm{NO}_{3}^{-}\right)$. These two groups of chemolithotrophic bacteria operate in sequence. Denitrification is the second step in the removal of nitrogen by nitrification/denitrification process. The reduction of nitrates back into the largely inert nitrogen gas $\left(\mathrm{N}_{2}\right)$ takes place during it. This process is performed by a great variety of bacterial species such as Pseudomonas, Alcaligenes, Acinetobacter, Clostridium, etc. They use the nitrate as an electron acceptor in the place of oxygen during respiration or-when oxygen is absent-they modify the cytochrome system and utilize nitrate.

The advantages of treatment leachate with activated sludge are possibility of its adaptation to any size of landfill and good elimination of some pollution parameters: total suspended solids, COD, and BOD, especially in case of young leachate. Disadvantages are relatively high capital costs and high energy consumption. The efficiency of activated sludge in leachate purification is presented in Table 4.

The denitrification consumes approximately $3.7 \mathrm{~g} \mathrm{COD} / \mathrm{g}$ $\mathrm{NO}_{3}-\mathrm{N}$ reduced (Chiu and Chung 2003) and produces $0.45 \mathrm{~g}$ new cell and $3.57 \mathrm{~g}$ of alkalinity per gram of $\mathrm{NO}_{3}-\mathrm{N}$ reduced (Eckenfelder and Musterman 1995). The removal efficiency of activated sludge for BOD ranged from 63 to $95 \%$ and for COD from 37 to $94.5 \%$. The activated sludge process is able to achieve over $90 \%$ removal of $\mathrm{N}-\mathrm{NH}_{4}{ }^{+}$. The removal rate for total nitrogen was below $50 \%$. The greatest differentiation was observed for P removal, which ranged from $17 \%$ according to Voronova et al. (2011) to over $80 \%$ according to Cicek et al. (1999). Activated sludge may be used together with reverse osmosis system giving a good pretreatment for 
Table 4 Performance of activated sludge treating landfill leachate

\begin{tabular}{|c|c|c|c|c|c|c|}
\hline Parameter & Influent (mg/L) & $\mathrm{BOD} / \mathrm{COD}$ & AS effluent (mg/L) & Removal (\%) & Type & References \\
\hline COD & 688 & 0.1 & - & 81 & $\begin{array}{l}\text { With ozonation } \\
\text { before AS stage }\end{array}$ & Geenens et al. (2000) \\
\hline COD & - & n.a. & - & 69 & n.a. & Bodzek et al. (2006) \\
\hline BOD & - & n.a. & 15 & $85-95$ & n.a. & Cicek et al. (1999) \\
\hline COD & - & & - & 94.5 & & \\
\hline TSS & $10-15$ & & - & 60.9 & & \\
\hline $\mathrm{N}-\mathrm{NH}_{4}^{+}$ & - & & - & 98.8 & & \\
\hline $\mathrm{P}_{\text {total }}$ & - & & $0.8-1$ & 88.5 & & \\
\hline BOD & $150-1630$ & n.a. & $45-525$ & 63 & n.a. & Voronova et al. (2011) \\
\hline COD & $988-8730$ & & $680-1960$ & 37 & & \\
\hline$P_{\text {total }}$ & $4.5-8.3$ & & $3.8-5.1$ & 17 & & \\
\hline $\mathrm{TN}$ & $200-603$ & & $30-395$ & 30 & & \\
\hline $\mathrm{N}-\mathrm{NH}_{4}^{+}$ & - & n.a. & $60-150$ & $<60$ & HRT: $1.5 \mathrm{~d}$ & Martienssen and Schops (1997) \\
\hline $\mathrm{TN}$ & - & & - & $<50$ & TOC: $1150 \mathrm{mg} / \mathrm{L}$ & \\
\hline COD & - & n.a. & - & 90 & n.a. & Shou-liang et al. (2008) \\
\hline $\mathrm{N}-\mathrm{NH}_{4}^{+}$ & $200-1400$ & & - & 90 & & \\
\hline BOD & - & n.a. & $10-500$ & $75-99$ & Laboratory scale & Akgul et al. (2013) \\
\hline
\end{tabular}

The activated sludge process used for leachate treatment is able to achieve over $60 \%$ efficiency in BOD and total suspended solids removal. The removal rate for total nitrogen was below 50\%. The high efficiency differentiation was observed in case of $\mathrm{N}-\mathrm{NH}_{4}^{+}$and $\mathrm{COD}$ removal, which ranged from 50 to $98.8 \%$ and from 37 to $94.5 \%$, respectively

$A S$ activated sludge, TSS total suspended solids, TN total nitrogen, HRT hydraulic retention time, TOC total organic carbon, n.a. data not available

landfill leachate. Activated sludge produces a secondary effluent which can be easily treated by a reverse osmosis system. Table 5 presents the effectiveness of reverse osmosis with activated sludge pretreatment in purification of landfill leachate.

A combination of activated sludge and reverse osmosis purification was studied for the treatment of stabilized leachate from Kolenfeld (Germany). The COD was reduced from the influent value of 3100 to $1160 \mathrm{mg} / \mathrm{L}$ in the effluent of the activated sludge step, meaning a $63 \%$ reduction rate of the total COD. More than $99 \% \mathrm{~N}-\mathrm{NH}_{4}{ }^{+}$was nitrified. As for the metals, the following average treatment efficiencies by the activated sludge step were obtained: Al 25\%, Fe 67\%, $\mathrm{Pb} 59 \%, \mathrm{Zn} \mathrm{58 \%}$, and $\mathrm{Cu} 58 \%$. After biological and reverse osmosis stages almost complete removal of suspended solids (more than 99.9\%) was obtained. The reduction rate of COD was greater than $99.5 \%$. Chloride was eliminated by more than $99 \%$, while over $98 \%$ of $\mathrm{N}-\mathrm{NH}_{4}{ }^{+}$was reduced. The overall reduction rates of $\mathrm{Al}, \mathrm{Fe}, \mathrm{Pb}, \mathrm{Zn}$, and $\mathrm{Cu}$ were above $98 \%$. The biological pretreatment was effective to reduce the biological organics as $\mathrm{BOD}_{5}$ and the main part of COD. However, the residual COD concentration after the biological processes was still high, confirming that biological treatment alone is insufficient for meeting the discharge standards (Li et al. 2009).

A two-stage treatment of young leachate (BOD/ $\mathrm{COD}=0.7$ ) from the Mechernich (Germany) consisting of activated sludge and reverse osmosis module was undertaken by Baumgarten and Sayfried (1996). With initial concentration of $6440 \mathrm{mg} / \mathrm{L}$ for COD and $1153 \mathrm{mg} / \mathrm{L}$ for $\mathrm{N}-\mathrm{NH}_{4}{ }^{+}$the removal rate of $99 \%$ was achieved for both of them. The results suggest that a combination of biological and physico-chemical treatment is able to optimize the removal of recalcitrant compounds and ammonia from landfill leachate.

\section{Rotating biological contactors and reverse osmosis}

The rotating biological contactor is an example of biological filter (attached growth) technology. It consists of a circular plastic disc mounted on a rotating shaft which is supported just above the surface of the wastewater (Wiszniowski et al. 2006). Commonly used plastics for the media are polyethylene, polyvinylchloride, and expanded polystyrene. The discs are submerged in wastewater to about $40 \%$ of their diameter and are slowly rotated by either mechanical or a compressed air drive (Wiszniowski et al. 2006) (Fig. 3).

The surface of the disc provides an attachment site for bacteria, and as the discs rotate, a film of biomass grows on their surface (The Attached Growth Process... 2004; Technology options... 2008). When the disc rotates out of the wastewater, the biofilm becomes exposed to air and so the oxygen necessary for the growth of microorganism is obtained (Crites and Tchobanoglous 1998; Wiszniowski et al. 2006). As the biofilm passes through the liquid 
Table 5 Effectiveness of reverse osmosis with activated sludge pretreatment in purification of landfill leachate

\begin{tabular}{|c|c|c|c|c|c|c|c|c|}
\hline Parameter & Influent & $\mathrm{BOD} / \mathrm{COD}$ & AS effluent & RO effluent & Removal & Type & Localization & References \\
\hline $\mathrm{pH}$ & 7.9 & \multirow[t]{13}{*}{ Old leachate } & 7.0 & 6.6 & n.a. & \multirow{13}{*}{$\begin{array}{l}\text { Activated sludge process } \\
\text { operated at a volumetric } \\
\text { load of } 2.6 \mathrm{~kg} \mathrm{COD} / \mathrm{m}^{3} \\
\text { day }\end{array}$} & \multirow[t]{13}{*}{ Kolenfeld, Germany } & \multirow[t]{13}{*}{ Li et al. (2009) } \\
\hline $\mathrm{EC}$ & 16.5 & & 16.3 & 0.3 & 98.2 & & & \\
\hline TSS & 315 & & 33 & Not detected & $>99.9$ & & & \\
\hline COD & 3100 & & 1160 & 15 & 99.5 & & & \\
\hline $\mathrm{N}-\mathrm{NH}_{4}^{+}$ & 1000 & & 6.5 & 11.3 & 99.8 & & & \\
\hline $\mathrm{N}-\mathrm{NO}_{2}^{-}$ & 5 & & 6.8 & 0.15 & 97 & & & \\
\hline $\mathrm{N}-\mathrm{NO}_{3}{ }^{-}$ & 15 & & 115 & 2.6 & 82.7 & & & \\
\hline $\mathrm{Cl}^{-}$ & 2850 & & 2790 & 23.2 & 99.2 & & & \\
\hline $\mathrm{Al}$ & 0.12 & & 0.09 & $<0.001$ & $>99.2$ & & & \\
\hline $\mathrm{Fe}$ & 7.6 & & 2.5 & $<0.001$ & $>99.9$ & & & \\
\hline $\mathrm{Pb}$ & 0.37 & & 0.15 & $<0.001$ & $>99.7$ & & & \\
\hline $\mathrm{Zn}$ & 0.65 & & 0.27 & $<0.001$ & $>99.8$ & & & \\
\hline $\mathrm{Cu}$ & 0.26 & & 0.11 & $<0.001$ & 99.6 & & & \\
\hline COD & 6440 & 0.70 & n.a. & n.a. & 99 & n.a. & Mechernich, Germany & $\begin{array}{l}\text { Baumgarten } \\
\text { and Sayfried } \\
\text { (1996) }\end{array}$ \\
\hline $\mathrm{N}-\mathrm{NH}_{4}^{+}$ & 1153 & & n.a. & n.a. & 99 & & & \\
\hline
\end{tabular}

It was noted a high efficiency (over 99\%) of activated sludge and reverse osmosis in $\mathrm{COD}, \mathrm{N}-\mathrm{NH}_{4}{ }^{+}$and total suspended solids removal. A combination of activated sludge and reverse osmosis had also a high removal rate for $\mathrm{Cl}^{-}, \mathrm{Al}, \mathrm{Fe}, \mathrm{Pb}, \mathrm{Zn}$, and $\mathrm{Cu}$. The efficiency for nitrogen nitrate and nitrogen nitrite was slightly lower $-97 \%$ and $82.7 \%$, respectively

Values of influent and effluent in $\mathrm{mg} / \mathrm{L}$ except for $\mathrm{pH}$ and $\mathrm{EC}(\mathrm{mS})$, removal effect in \%

$A S$ activated sludge, $R O$ reverse osmosis, $E C$ electroconductivity, TSS total suspended solids, n.a. data not available

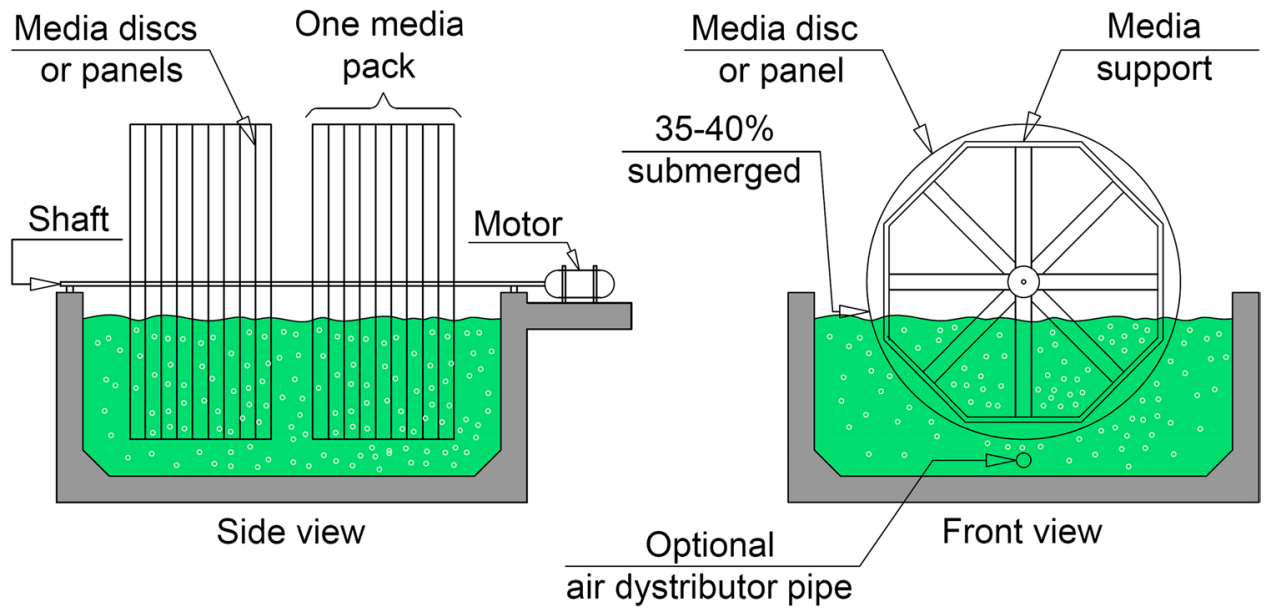

Fig. 3 Rotating biological contactors are fixed-bed reactors consisting of rotating discs mounted on a horizontal shaft. The surface of the discs provides an attachment site for bacteria. The microbial community is alternately exposed to the atmosphere and the leachate/wastewater. The oxygen necessary for the growth of these microorganisms

phase, nutrients and organic pollutants are taken up. All oxygen, nutrients, and organic pollutants are necessary for the growth of the microorganism and the conversion of the organic matter to $\mathrm{CO}_{2}$. Nitrogen is removed by nitrification and subsequent denitrification transforming it to gaseous $\mathrm{N}_{2}$, which is released to the air. The process is optimized is obtained by adsorption from the air as the biofilm on the disc is rotated out of the liquid. This microbial population causes the biological degradation of organic pollutants. Source: Adapted from http:// en.wikipedia.org/wiki/Rotating_biological_contactor

by adjusting the speed of rotation and the depth of submergence. In some designs, air is added to the bottom of the tank to provide additional oxygen in case of high-strength influents (Crites and Tchobanoglous 1998). As for all fixedfilm processes, primary settling and/or screening is required for the removal of excessive oil or grease prior to rotating 
biological contactor process (Technology options... 2008). Such primary treatments are typically septic tanks, Imhoff tanks, or anaerobic reactors.

The performance of rotating biological contactor systems depends on the design, the temperature, the concentration of the pollutants, the rotating velocity, and the hydraulic retention time. Rotating biological contactors can achieve biological oxygen demand reductions of 80-90\% (Technology options... 2008). The removal of nitrogen (which is mostly present as ammonia) by nitrification and subsequent denitrification is also high, because both aerobic nitrifying bacteria and anaerobic denitrifying bacteria can simultaneously live in the attached biofilm, depending on whether they are situated on the bottom of the film, close to the disc support (and thus in anaerobic or anoxic conditions), or at the top of the film exposed to the air (Hochheimer and Wheton 1998).

The collected sludge in the clarifier requires further treatment for stabilization, such as anaerobic digestion, composting, constructed wetlands, ponds, or drying (Technology options... 2008). Effluents from rotating biological contactor, due to the reduced removal of microorganisms, require a further treatment. Treating high-organic polluted leachates may result in clogging by means of inorganic precipitates and/or produced biomass. On the other hand, in many cases nitrification processes are more effective in fixed-film reactors due to the high sludge age. For this reason these treatment methods are more appropriate for the treatment of leachate from old landfills (Stegmann et al. 2005).

The rotating biological contactor process appears to offer several advantages over the activated sludge process for use in landfill leachate treatment. The primary advantage of rotating biological contactors is the relative ease of operation and maintenance. This treatment method consumes relatively low amounts of energy, simple operation requires less maintenance and monitoring than the activated sludge, and lower sensitivity to load variations and toxins is observed (Wiszniowski et al. 2006). Table 6 shows the results of rotating biological contactor process treating leachate on different landfills.

The rotating biological contactor process employed at El Carrasco landfill (Colombia) operated with an organic load of $24.7 \mathrm{~g} \mathrm{COD} / \mathrm{m}^{2}$ per day with hydraulic retention time of $34 \mathrm{~h}$, and angular speeds of 6 and $9 \mathrm{rpm}$ gave a maximum COD removal of $58.5 \%$ (Castillo et al. 2007). A rotating biological contactor was also used to remove nitrogen from a high-ammonia landfill leachate collected from a municipal solid waste landfill in Kaohsiung (Taiwan). The research indicated that greater than $95 \%$ ammonia removal from high-ammonia-N (2142 mg/L) leachate can be achieved with rotating biological contactor ammonia-N loading rates up to $1.5 \mathrm{~g} /\left(\mathrm{m}^{2}\right.$ day $)$. At rotating biological contactor loading rates of $1.5-3.0 \mathrm{~g} /\left(\mathrm{m}^{2}\right.$ day $)$, ammonia removal ranged from 80 to $90 \%$. Nitrogen removal averaged 54\%. BOD and
COD removal averaged $92 \%$ and $49 \%$, respectively. Overall removal of dissolved metals ranged from $19 \%$ for nickel to $59 \%$ for manganese (Henderson and Atwater 1995). The denitrification performance of a laboratory-scale rotating biological contactor using landfill leachate-from a municipal landfill in the North of Portugal—with high nitrate concentration was evaluated by Cortez et al. (2011). Under a carbon-to-nitrogen ratio $(\mathrm{C} / \mathrm{N})$ of 2 , the reactor achieved $\mathrm{N}-\mathrm{NO}_{3}$-removal efficiencies above $95 \%$ for concentrations up to $100 \mathrm{mg} \mathrm{N}-\mathrm{NO}_{3}-$ per $1 \mathrm{~L}$. The effectiveness of COD removal was about $90 \%$. In Vicevic et al.'s (2005) study the rotating biological contactor system averaged COD and BOD removal efficiency of $84 \%$ and $94 \%$, respectively.

Biological reactor has also the capability to remove some metals. The mechanism by which this removal takes place is known as a bio-adsorption. Anaerobic system also removes metals by the reduction of sulphate to insoluble metal sulphides as the samples of sludge from rotating biological contactor reactor showed high concentration of these metals (Vicevic et al. 2005). Results of Torabian et al. (2004) showed that anaerobic reactor with detention time of 4.5 days had a $44 \%$ COD removal. The effluent COD of sequencing batch reactor was $21,309 \mathrm{mg} / \mathrm{L}$. The removal of phosphorus was quite high- $71 \%$. The effectiveness for nitrate and nitrite removal was $32 \%$ and $33 \%$, respectively.

Effluents from rotating biological contactor require a further treatment. One of the treatment possibilities can be the use of reverse osmosis. There are no too many data concerning leachate treatment by rotating biological contactor followed by reverse osmosis. In Table 7 the effectiveness of reverse osmosis with rotating biological contactor pretreatment in purification of landfill leachate from Mechernich landfill (Germany) is presented. The rotating biological contactor plant was designed for a nitrogen loading of $2 \mathrm{~g} \mathrm{~N} /$ $\mathrm{m}^{2}$.day. The contactor surface of $65,000 \mathrm{~m}^{2}$ was divided into four lines with three biological contactors in series. The reverse osmosis was a two-stage plant. The first stage was equipped with tubular modules with cellulose acetate membranes. The second stage was equipped with composite membranes in spiral wound modules. Membrane plants were designed for leachate flow of $65-130 \mathrm{~m}^{2} /$ day (Baumgarten and Sayfried 1996).

In the analysed treatment plant at Mechernich landfill the COD and BOD initial value was reduced by over $99 \%$. The average COD value in permeate was $16.8 \mathrm{mg} / \mathrm{L}$ and BOD value $-2.11 \mathrm{mg} / \mathrm{L}$. The $97 \%$ of BOD removal was performed in rotating biological contactor. The rotating biological contactor pretreatment caused the big reduction of nitrogen compounds such as $\mathrm{N}-\mathrm{NH}_{4}{ }^{+}$, total organic nitrogen, and total inorganic nitrogen. The removal effects after rotating biological contactor were $99 \%$ for $\mathrm{N}-\mathrm{NH}_{4}^{+}, 86 \%$ for total inorganic nitrogen, and $67 \%$ for total organic nitrogen. The total removal effects for these compounds were over $97 \%$. 
Table 6 Performance of rotating biological contactor treating landfill leachate

\begin{tabular}{|c|c|c|c|c|c|c|}
\hline Parameter & Influent (mg/L) & $\mathrm{BOD} / \mathrm{COD}$ & $\begin{array}{l}\text { RBC effluent } \\
(\mathrm{mg} / \mathrm{L})\end{array}$ & Removal (\%) & Type & References \\
\hline COD & 3950 & 0.67 & - & 53.4 & $\begin{array}{l}\mathrm{HRT}=34 \\
\mathrm{rpm}=3\end{array}$ & Castillo et al. (2007) \\
\hline COD & 3950 & & - & 58.5 & $\begin{array}{l}\mathrm{HRT}=34 \\
\mathrm{rpm}=6\end{array}$ & \\
\hline COD & 3950 & & - & 58.5 & $\begin{array}{l}\mathrm{HRT}=34 \\
\mathrm{rpm}=9\end{array}$ & \\
\hline COD & 5040 & 0.1 & 2660 & 49 & $\mathrm{rpm}=10-25$ & Henderson and Atwater (1995) \\
\hline BOD & 705 & & 63 & 92 & & \\
\hline $\mathrm{N}-\mathrm{NH}_{4}^{+}$ & 2142 & & 222 & $\approx 90$ & & \\
\hline $\mathrm{Ni}$ & 0.00113 & & 0.00091 & 19.5 & & \\
\hline $\mathrm{Fe}$ & 7.3 & & 4.59 & 37 & & \\
\hline $\mathrm{Mn}$ & 0.77 & & 0.32 & 59 & & \\
\hline $\mathrm{N}-\mathrm{NO}_{3}{ }^{-}$ & 560 & $<0.5$ & - & $>95$ & n.a. & Cortez et al. (2011) \\
\hline COD & - & - & $\approx 90$ & & & \\
\hline BOD & 5340 & 0.6 & - & 94 & n.a. & Vicevic et al. (2005) \\
\hline COD & 9254 & & - & 84 & & \\
\hline $\mathrm{Zn}$ & 3.6 & & - & 92 & & \\
\hline $\mathrm{Mn}$ & 7.6 & & - & 82 & & \\
\hline $\mathrm{Ca}$ & 700 & & - & 92 & & \\
\hline $\mathrm{Mg}$ & 339 & & - & 19 & & \\
\hline $\mathrm{Cr}$ & 0.14 & & - & 70 & & \\
\hline $\mathrm{Ni}$ & 0.83 & & - & 46 & & \\
\hline COD & - & n.a. & 21,309 & 44 & n.a & Torabian et al. (2004) \\
\hline$P_{\text {total }}$ & - & & 27 & 71 & & \\
\hline $\mathrm{N}-\mathrm{NO}_{3}^{-}$ & - & & 100 & 32 & & \\
\hline $\mathrm{N}-\mathrm{NO}_{2}^{-}$ & - & & 0.6 & 33 & & \\
\hline
\end{tabular}

The use of rotating biological contactor for landfill leachate treatment gave an efficiency of above 90\% for BOD removal. The removal rates for $\mathrm{COD}$ and $\mathrm{N}_{-} \mathrm{NO}_{3}{ }^{-}$were characterized by a high variability and ranged from 44 to $90 \%$ for COD and from 32 to $95 \%$ for nitrogen nitrite. The lowest treatment efficiency was observed for metals $(\mathrm{Ni}, \mathrm{Fe}, \mathrm{Cr}, \mathrm{Ni})$ and $\mathrm{Ca}$

$H R T$ hydraulic retention time, rpm revolutions per minute (speed), n.a. data not available

The lower removal efficiency was noted for $\mathrm{N}^{-\mathrm{NO}_{3}}{ }^{-}(68 \%)$ and $\mathrm{N}-\mathrm{NO}_{2}{ }^{-}(20 \%)$. The use of reverse osmosis as one of the stages of leachate treatment gave good purification results for $\mathrm{Pb}-99 \%$, adsorbable organohalogens-more than $99 \%$, and $\mathrm{Cl}^{-} \_98 \%$ (Baumgarten and Sayfried 1996).

\section{Up-flow anaerobic sludge blanket and reverse osmosis}

Up-flow anaerobic sludge blanket is found as one of the most studied biological processes for leachate treatment. It involves biological decomposition of organic and inorganic matter in the absence of molecular oxygen (Wiszniowski et al. 2006). The up-flow anaerobic sludge blanket plant design consists of a biological reaction zone and a sedimentation zone (Fig. 4).

Leachate is pumped from the bottom into reactor where influent suspended solids and bacterial activity and growth lead to the formation of sludge. The sludge blanket is comprised of microbial granules of $1-3 \mathrm{~mm}$ in diameter. As the flow passes upwards through bed of activated sludge, bacteria living in the sludge break down organic matter by anaerobic digestion, transforming it into biogas (methane and carbon dioxide). The rising bubbles mix the sludge without the assistance of any mechanical parts. After several weeks of use, larger granules of sludge form, which act as a filter for smaller particles as the effluent rises through the cushion of sludge. In the up-flow anaerobic sludge blanket reactor, the substrate degradation occurs mainly in the lower part of the reactor due to the presence of a high concentration of active anaerobic sludge, effective mixing of the incoming wastewater flow with the partially purified water present in the upper part of reactor, and the occurrence of colloidal particles, precipitation, and sedimentation.

The clarified effluent is extracted from the top of the tank in an area above the sloped walls. A gas-liquid-solids 
Table 7 Effectiveness of reverse osmosis with rotating biological contactor pretreatment in purification of landfill leachate

\begin{tabular}{|c|c|c|c|c|c|c|c|c|}
\hline Parameter & Influent & $\mathrm{BOD} / \mathrm{COD}$ & $\mathrm{RBC}$ effluent & RO effluent & Removal & Type & Localization & References \\
\hline COD & 3176 & $\approx 0.3$ & 1301 & 16.8 & 99 & Contactor surface: & $\begin{array}{l}\text { Mechernich land- } \\
\text { fill, Germany } \\
\text { Full scale }\end{array}$ & $\begin{array}{l}\text { Baumgarten } \\
\text { and Sayfried } \\
(1996)\end{array}$ \\
\hline BOD & 1062 & & 23.7 & 2.11 & $>99$ & $65,000 \mathrm{~m}^{2}$ & & \\
\hline TON & 251 & & 82.1 & 5.71 & 97 & Two-stage RO & & \\
\hline $\mathrm{N}-\mathrm{NH}_{4}^{+}$ & 884 & & 1.9 & 0.48 & 99 & Leachate flow & & \\
\hline $\mathrm{N}-\mathrm{NO}_{3}^{-}$ & 32 & & 129 & 10 & 68 & of $65-130 \mathrm{~m}^{2} /$ day & & \\
\hline $\mathrm{N}-\mathrm{NO}_{2}^{-}$ & 0.1 & & 2.4 & 0.12 & 20 & & & \\
\hline TIN & 916 & & 131.2 & 10.6 & 98 & & & \\
\hline $\mathrm{Pb}$ & 0.593 & & 0.142 & $<0.001$ & 99 & & & \\
\hline AOX & 1261 & & 775 & $<0.01$ & $>99$ & & & \\
\hline $\mathrm{Cl}^{-}$ & 2172 & & 2010 & 29 & 98 & & & \\
\hline
\end{tabular}

A combination of rotating biological contactor with reverse osmosis gave a very good result in removal of organic parameters, such as BOD (>99\% removal), COD (99\%), total organic nitrogen (97\%), and adsorbable organohalogens (>99\%). A high treatment efficiency was also observed for inorganics: $\mathrm{N}-\mathrm{NH}_{4}^{+}$, total inorganic nitrogen, $\mathrm{Pb}$, and $\mathrm{Cl}^{-}$. The lowest removal effect was noted for $\mathrm{N}^{-} \mathrm{NO}_{2}^{-}(20 \%)$

Values of influent and effluent in $\mathrm{mg} / \mathrm{L}$ except for $\mathrm{pH}$ and $\mathrm{EC}(\mathrm{mS})$, removal effect in \%

$R B C$ rotating biological contactor, $R O$ reverse osmosis, TON total organic nitrogen, $T I N$ total inorganic nitrogen, $A O X$ adsorbable organohalogens, n.a. data not available

separator separates the gas from the treated wastewater and the sludge. The $\mathrm{pH}$ value needs to be between 6.3 and 7.85 to allow the bacteria responsible for anaerobic digestion to grow. For an optimal growth of these bacteria and thus an optimal anaerobic digestion, the temperature should lie between 35 and $38{ }^{\circ} \mathrm{C}$ (Anaerobic Treatment...2001).

The optimal hydraulic retention time generally lies within 2-20 h because at lower hydraulic retention times, the possibility of washout of biomass is more prominent (Bal and Dhagat 2001). The up-flow anaerobic sludge blanket process has several advantages over other anaerobic processes. It is simple to construct and operate and is able to tolerate high organic and hydraulic loading rates. The key feature of the up-flow anaerobic sludge blanket process, that allows the use of high volumetric COD loadings compared to other anaerobic process, is the development of dense granulated sludge (Li et al. 1995).

Conventionally, an up-flow anaerobic sludge blanket has mostly been installed in leachate treatment process for treating high-loading organic compounds discharged from young landfills (Im et al. 2001). Table 8 presents the result of up-flow anaerobic sludge blanket process in treating leachate from different landfills. Singh and Mittal (2012) report the applicability of up-flow anaerobic sludge blanket process to treat the leachate from a municipal Okhla landfill located in Delhi (India). A laboratory-scale reactor was operated at an organic loading rate of $3 \mathrm{~kg} \mathrm{COD} / \mathrm{L} \bullet$ day corresponding to a hydraulic retention time of $12 \mathrm{~h}$ for over 8 months. The removal efficiency of soluble COD ranged between 67 and $91 \%$ for fresh leachate and decreased drastically from 90 to $35 \%$ for old leachate. The use of up-flow anaerobic sludge blanket reactor for leachate treatment at the Istanbul Kömürcüoda landfill (Turkey) provided over $80 \%$ of BOD and COD removal in young leachate samples. The organic loading rate ranged from 0.75 to $8 \mathrm{~kg}$ COD/L•day (Akgul et al. 2013). Data from landfills with up-flow anaerobic sludge blanket treatment process show that the BOD/COD ratio profoundly impacts upon effluent quality (Alvarez-Vazquez et al. 2004). Kettunen and Rintala (1998) reported a 63-75\% COD removal from a young leachate matrix. In Keenan et al. (1991) up-flow anaerobic sludge blanket study, a 90\% COD removal was achieved in a medium-aged leachate. Treating of leachate using up-flow anaerobic sludge blanket reactor at OttawaCarleton Landfill (Canada) was investigated by Kennedy and Lentz (2000). The up-flow anaerobic sludge blanket was operated at organic loading rates between 4.8 and 19.7 g COD l•day. The up-flow anaerobic sludge blanket reactor had soluble COD removal efficiencies ranging between 77 and $81 \%$ at hydraulic retention time of 24,18 , and $12 \mathrm{~h}$. Removal effects for phosphorus, chlorides, and sulphides were below $50 \%$; nevertheless, the concentrations of the effluents from reactor were below guideline concentration. The up-flow anaerobic sludge blanket had a sulphate removal efficiency of $81 \%$ and zinc removal efficiency of $75 \%$ (Kennedy and Lentz 2000). Research conducted by Calli et al. (2006) indicated that landfill leachate containing total ammonia concentration above $2000 \mathrm{mg} / \mathrm{L}$ can be treated successfully by using up-flow anaerobic sludge blanket. By reducing the influent $\mathrm{pH}$ to 4.5 to control the free ammonia levels in the reactors, COD removal 


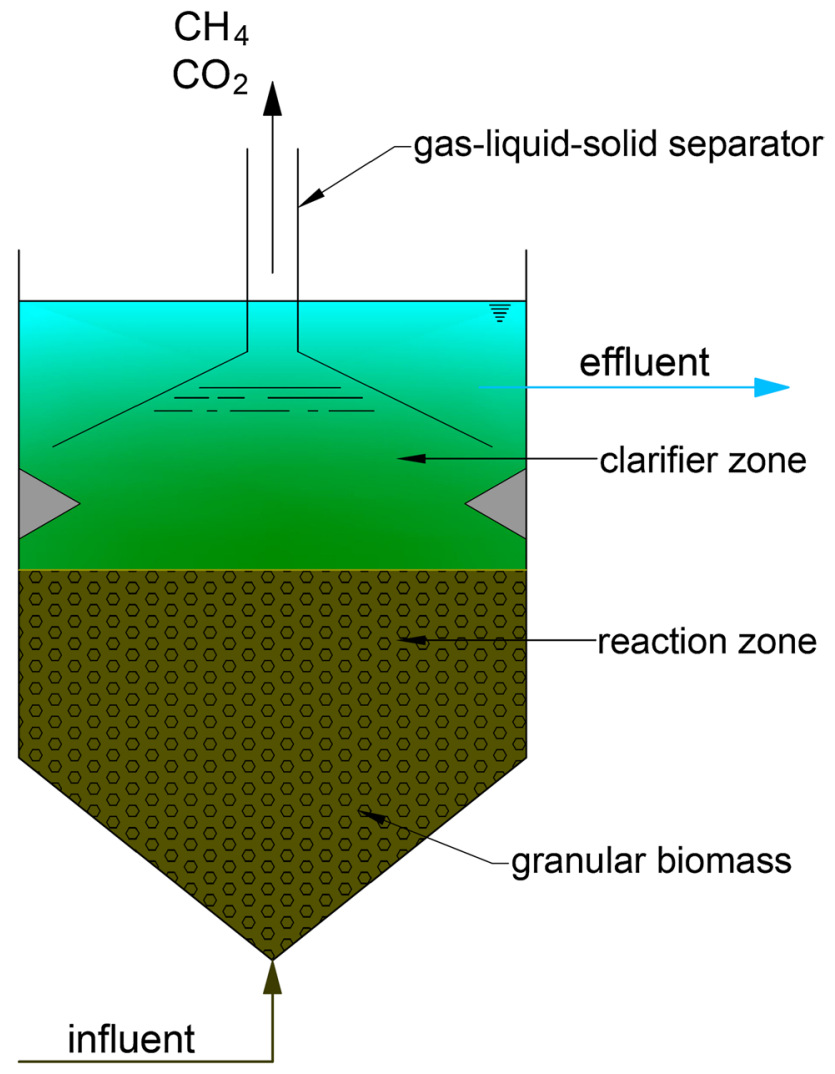

Fig. 4 Schematic diagram of an up-flow anaerobic sludge blanket. Leachate enters the reactor from the bottom and flows upwards. A suspended sludge blanket, which is comprised of microbial granules, filters and treats the leachate as the leachate flows through it. As a result of organic degradation, gases (methane and carbon dioxide) are released. The rising bubbles mix the sludge without the assistance of any mechanical parts. The clarified effluent is extracted from the top of the tank in an area above the sloped walls. Source: Adapted from http://www.engineeringfundamentals.net/UASBs/fundamentals.htm

efficiencies above $80 \%$ were achieved without any significant loss in methanogenic activity (Calli et al. 2006).

The up-flow anaerobic sludge blanket technology is widely and effectively accepted for treating young leachate with high BOD concentration (Kurniawan et al. 2006; Khan et al. 2013). However, COD removal from old landfill leachate presents a challenging problem for this conventional biological treatment due to the presence of bio-refractory and toxic contaminants, resulting in the requirement of multi-stage operations and large footprint systems to achieve moderate results (Ahmed and Lan 2012). Successful leachate treatment requires addition of non-biological stage such as among other membrane separation (Ahmed and Lan 2012). Bohdziewicz and Kwarciak (2008) showed an effective removal of leachate contaminants by using reverse osmosis following up-flow anaerobic sludge blanket (Table 9).
In their study an up-flow anaerobic sludge blanket reactor was operated at a hydraulic retention time of between 7 and 2 days and organic loading rate ranging between 0.6 and $2.0 \mathrm{~kg} \mathrm{COD} / \mathrm{m}^{3} \cdot$ day. The hydraulic retention time of 3 days and organic loading time of $1.3 \mathrm{~kg} \mathrm{COD} / \mathrm{m}^{3} \bullet$ day were taken as the optimum fermentation process parameters. Under such designed conditions COD removal after up-flow anaerobic sludge blanket achieved a value of $76 \%$. The concentration of COD, BOD, ammonia nitrogen, chloride concentration in up-flow anaerobic sludge blanket effluent was kept on the level of $960 \mathrm{mg} \mathrm{O}_{2} / \mathrm{L}, 245 \mathrm{mg} \mathrm{O}_{2} / \mathrm{L}, 196 \mathrm{mg} \mathrm{NH}_{4}^{+} / \mathrm{L}$, and $2350 \mathrm{mg} \mathrm{Cl}^{-} / \mathrm{L}$, respectively. Due to poor quality of up-flow anaerobic sludge blanket effluent, leachate was put into the post-treatment process. In reverse osmosis process COD, BOD, chloride, ammonia nitrogen parameters were removed in $95.4,90.2,85.4$, and $88.7 \%$, respectively.

A combination of an up-flow anaerobic sludge blanket reactors and reverse osmosis was studied for the treatment of stabilized leachate from the Bavel landfill (Netherlands) (Kurniawan et al. 2006). The up-flow anaerobic sludge blanket reactor was employed for pretreatment of leachate (Table 9). Since recalcitrant compounds with initial COD and $\mathrm{N}-\mathrm{NH}_{4}{ }^{+}$concentrations of 35,000 and $1600 \mathrm{mg} / \mathrm{L}$, respectively, were able to be completely removed from the leachate, the effluent was discharged to surface water without further treatment (Jans et al. 1992; Kurniawan et al. 2006).

\section{Comparison of biological pretreatments for leachate purification with reverse osmosis}

To evaluate the reverse osmosis performance with different biological pretreatments a brief comparative study in terms of $\mathrm{COD}, \mathrm{BOD}, \mathrm{N}-\mathrm{NH}_{4}{ }^{+}, \mathrm{Cl}^{-}, \mathrm{Pb}, \mathrm{N}-\mathrm{NO}_{2}{ }^{-}, \mathrm{N}-\mathrm{NO}_{3}{ }^{-}$, and total suspended solids was done (Table 10).

Although it has a relative meaning due to different testing conditions $(\mathrm{pH}$, temperature, strength of leachate, seasonal climate changes, operation conditions), this comparison is useful to evaluate the overall treatment performance of each technique for helping the decision-making process.

It is found that the COD removal effect is similar in all analysed leachate treatments and ranged from 97 to $99 \%$ in combination reverse osmosis with membrane bioreactor pretreatment to $99-99.5 \%$ in reverse osmosis with activated sludge. Nevertheless, the more stable removal effect of $99 \%$ seems to be in up-flow anaerobic sludge blanket followed by reverse osmosis. The BOD removal achieved $91 \%$ in combination reverse osmosis and up-flow anaerobic sludge blanket, $97 \%$ in reverse osmosis with membrane bioreactor pretreatment, and over $99 \%$ in reverse osmosis and rotating biological contactor. With the passing of time concentrate (or leachate) recirculation affects the increase in ammonia 
Table 8 Performance of up-flow anaerobic sludge blanket treating landfill leachate

\begin{tabular}{|c|c|c|c|c|c|c|}
\hline Parameter & Influent (mg/L) & $\mathrm{BOD} / \mathrm{COD}$ & $\begin{array}{l}\text { UASB effluent } \\
(\mathrm{mg} / \mathrm{L})\end{array}$ & Removal (\%) & Type & References \\
\hline COD & $88,000-66,420$ & n.a. & - & $\begin{array}{l}61-97 * \\
35 * *\end{array}$ & $\begin{array}{l}\mathrm{OLR}=3 \mathrm{~kg} \\
\mathrm{COD} / \mathrm{L} \cdot \text { day } \\
\mathrm{HRT}=12 \mathrm{~h} \\
\text { Laboratory scale }\end{array}$ & Singh and Mittal (2012) \\
\hline BOD & $4640-27,465$ & 0.75 & - & $>80$ & $\mathrm{OLR}=0.75-8 \mathrm{~kg}$ & Akgul et al. (2013) \\
\hline COD & $10,695-37,760$ & & - & $>80$ & $\begin{array}{l}\mathrm{COD} / \mathrm{L} \cdot \text { day } \\
\mathrm{HRT}=24 \mathrm{~h} \\
\text { Laboratory scale }\end{array}$ & \\
\hline COD & 3100 & 0.6 & - & 63 & On-site & Kettunen and Rintala (1998) \\
\hline COD & 1900 & 0.63 & - & 75 & & \\
\hline COD & 29,000 & 0.5 & - & 90 & Pilot scale & Keenan et al. (1991) \\
\hline COD & $4800-9840$ & n.a. & $600-1750$ & $\begin{array}{l}78 \\
81 \\
77\end{array}$ & $\begin{array}{l}\text { OLR }=4.8-19.7 \\
\mathrm{~g} \mathrm{COD} / \mathrm{L} \cdot \text { day } \\
\text { Laboratory scale } \\
\mathrm{HRT}=24 \mathrm{~h} \\
\mathrm{HRT}=18 \mathrm{~h} \\
\mathrm{HRT}=12 \mathrm{~h}\end{array}$ & Kennedy and Lentz (2000) \\
\hline $\mathrm{Cl}^{-}$ & 3035 & & 2352 & 22 & & \\
\hline $\mathrm{SO}_{4}^{2-}$ & 165 & & 31 & 81 & & \\
\hline $\mathrm{P}_{\text {total }}$ & 2 & & 2 & $<1$ & & \\
\hline $\mathrm{Zn}$ & 0.4 & & 0.1 & 75 & & \\
\hline $\mathrm{S}^{-}$ & 35 & & 18 & 48 & & \\
\hline COD & - & n.a. & - & 80 & $\begin{array}{l}\mathrm{OLR}=1.3-23.5 \\
\mathrm{Kg} \text { COD m}{ }^{3} \cdot \text { day } \\
\text { Laboratory scale }\end{array}$ & Calli et al. (2006) \\
\hline
\end{tabular}

The up-flow anaerobic sludge blanket process is able to achieve over 80\% removal of BOD. But according to Ahmed and Lan (2012) the process is not enough efficient in COD reduction, especially from stabilized leachate, because of high concentration of refractory and toxic compounds $U A S B$ up-flow anaerobic sludge blanket, $O L R$ organic loading rate, $H R T$ hydraulic retention time, rpm revolutions per minute, n.a. data not available

*Young leachate, **Old leachate

Table 9 Effectiveness of reverse osmosis with up-flow anaerobic sludge blanket pretreatment in purification of landfill leachate

\begin{tabular}{|c|c|c|c|c|c|c|c|c|}
\hline Parameter & Influent & BOD/COD & UASB effluent & RO effluent & Removal & Type & Localization & References \\
\hline COD & 4000 & 0.3 & 960 & 44 & n.a. & HRT: 7-2 days & Sobuczyna & $\begin{array}{l}\text { Bohdziewicz } \\
\text { and Kwarciak } \\
\text { (2008) }\end{array}$ \\
\hline BOD & 280 & & 245 & 24 & n.a. & OLR: $0.6-2.0 \mathrm{~kg}$ & landfill & \\
\hline $\mathrm{N}-\mathrm{NH}_{4}^{+}$ & 890-994 & & 196 & 22 & n.a. & $\mathrm{COD} / \mathrm{m}^{3} \bullet$ day & (Poland) & \\
\hline $\mathrm{Cl}$ & 2500 & & 2350 & 215 & n.a. & & Laboratory scale & \\
\hline COD & $25,000-35,000$ & n.a. & $3000-5000$ & $5-8$ & 99 & HRT: 8-12 h & Bavel landfill & Jans et al. (1992) \\
\hline $\mathrm{TN}$ & 1600 & & 1550 & n.a. & 99 & OLR: $25 \mathrm{~kg}$ COD/ & (Netherlands) & \\
\hline TSS & $0-50$ & & $150-200$ & n.a & 10 & $/ \mathrm{m}^{3} \cdot$ day & Full scale & \\
\hline
\end{tabular}

The use of reverse osmosis as a second step of leachate treatment significantly improved the efficiency of COD and nitrogen compounds removal to over $90 \%$. However, combination of reverse osmosis and up-flow anaerobic sludge blanket may be inefficient in reduction of suspended solids due to the generation of additional quantities of suspended solids during biological decomposition in up-flow anaerobic process

Values of influent and effluent in $\mathrm{mg} / \mathrm{L}$ except for $\mathrm{pH}$ and $\mathrm{EC}(\mathrm{mS})$, removal effect in \%

$U A S B$ up-flow anaerobic sludge blanket, $R O$ reverse osmosis, $T N$ total nitrogen, $T S S$ total suspended solids, HRT hydraulic retention time, $O L R$ organic loading rate, n.a. data not available 
Table 10 Comparison of reverse osmosis performance with different biological pretreatments during leachate purification

\begin{tabular}{lllllllll}
\hline \multicolumn{1}{l}{ Removal performance (\%) } \\
\cline { 2 - 8 } & COD & BOD & ${\mathrm{N}-\mathrm{NH}_{4}^{+}}^{+}$ & $\mathrm{Cl}^{-}$ & $\mathrm{Pb}$ & $\mathrm{N}-\mathrm{NO}_{2}^{-}$ & ${\mathrm{N}-\mathrm{NO}_{3}^{-}}^{-}$ & TSS \\
\hline MBR and RO & $97-99$ & 97 & $92-96$ & n.a. & n.a. & n.a. & n.a. & 99 \\
AS and RO & $99-99.5$ & n.a. & $99-99.8$ & 99.2 & $>99.7$ & 97 & 83 & $>99.9$ \\
RBC and RO & 99 & $>99$ & 99 & 98 & 99 & 20 & 68 & n.a. \\
UASB and RO & 99 & 91 & 97 & 91 & n.a. & n.a. & n.a. & 10 \\
\hline
\end{tabular}

Comparing the combination of reverse osmosis with different biological pretreatment methods one can observe the high effectiveness (over 90\%) in COD, BOD, N- $\mathrm{NH}_{4}^{+}, \mathrm{Cl}^{-}$removal for all analysed methods. Rotating biological contactor followed by reverse osmosis had the lower reduction rate for nitrite and nitrate ammonia. Combination of up-flow anaerobic sludge blanket and reverse osmosis is insufficient in suspended solids removal

TSS total suspended solids, $R O$ reverse osmosis, $M B R$ membrane bioreactor, $A S$ activated sludge, $R B C$ rotating biological contactor, $U A S B$ up-flow anaerobic sludge blanket, n.a. data not available concentration in landfill leachate. That is why a very important issue is the $\mathrm{N}-\mathrm{NH}_{4}{ }^{+}$removal from leachate.

The almost complete $\mathrm{N}-\mathrm{NH}_{4}{ }^{+}$removal (99-99.8\%) was achieved in activated sludge followed by reverse osmosis. The high efficiency of 97 and 99\% was also observed for upflow anaerobic sludge blanket and rotating biological contactor, respectively. The chloride removal ranged from $91 \%$ in reverse osmosis and up-flow anaerobic sludge blanket to over $99 \%$ in reverse osmosis and activated sludge. There are also some data concerning $\mathrm{N}-\mathrm{NO}_{2}{ }^{-}$and $\mathrm{N}-\mathrm{NO}_{3}{ }^{-}$removal, which were highest (97 and 83\%) in combination reverse osmosis and activated sludge. A very significant issue in leachate treatment with the use of reverse osmosis is total suspended solids removal before the process. It can contribute to prolongation of membrane's lifetime and to the decrease in exploitation cost. The almost complete total suspended solids removal was observed for reverse osmosis and activated sludge (over 99.9\%) and reverse osmosis and membrane bioreactor (99\%). The combination of reverse osmosis and up-flow anaerobic sludge blanket gave $10 \%$ effectiveness in total suspended solids reduction.

Biological pretreatment has many advantages for leachate treatment by reverse osmosis. It increases the final removal effect especially in terms of organic compounds. The conventional biological systems are usually easy in operation and simple in exploitation. They are suitable for pretreatment of leachate to complete the biological degradation process.

\section{Conclusion}

In order to meet the strict quality standards for leachate discharge, an integrated biological and physico-chemical method of treatment has been developed. The presented data have shown that all analysed combinations of biological pretreatment followed by reverse osmosis are effective in removing COD, BOD, and $\mathrm{N}-\mathrm{NH}_{4}{ }^{+}$from landfill leachate. Almost complete removal of both $\mathrm{COD}$ and $\mathrm{N}-\mathrm{NH}_{4}{ }^{+}$ has been accomplished by a combination of reverse osmosis and activated sludge. The highest removal of BOD has been achieved using reverse osmosis and rotating biological contactor.

Both activated sludge and rotating biological contactor in combination with reverse osmosis were effective in $\mathrm{Cl}^{-}$and $\mathrm{Pb}$ removal (over 98\%). Activated sludge followed by reverse osmosis gave a good result in reduction of $\mathrm{N}-\mathrm{NO}_{2}{ }^{-}$and $\mathrm{N}-\mathrm{NO}_{3}{ }^{-}$from leachate influent. A high total suspended solids removal effect (99 and 100\%) provided by membrane bioreactor and activated sludge permits further treatment by reverse osmosis and suppresses fouling of membrane.

It is important to note that the selection of the most suitable treatment technology for landfill leachate depends on the quality and quantity of leachate, age of landfill, plant flexibility, and operating conditions. Economic parameters also play an important role in this decision-making process.

Acknowledgements The paper was created during realization of a scientific work No. S/WBiIS/2/2014 financed by Polish Ministry of Science and Higher Education.

Open Access This article is distributed under the terms of the Creative Commons Attribution 4.0 International License (http://creativeco mmons.org/licenses/by/4.0/), which permits unrestricted use, distribution, and reproduction in any medium, provided you give appropriate credit to the original author(s) and the source, provide a link to the Creative Commons license, and indicate if changes were made.

\section{References}

Ahmed FN, Lan ChQ (2012) Treatment of landfill leachate using membrane bioreactors: a review. Desalination 287:41-45. https://doi. org/10.1016/j.desal.2011.12.012

Ahn WY, Kang MS, Yim SK, Choi KH (2001) Advanced landfill leachate treatment using an integrated membrane process. Desalination 149:109-114. https://doi.org/10.1016/S0011-9164(02)00740-3 
Akgul D, Aktan CK, Yapsakli K, Mertoglu B (2013) Treatment of landfill leachate using UASB-MBR-SHARON-Anammox configuration. Biodegradation 24:399-412. https://doi.org/10.1007/s10532-012-9597-y

Alvarez-Vazquez B, Jefferson B, Judd SJ (2004) Membrane bioreactors vs conventional biological treatment of landfill leachate: a brief review. J Chem Technol Biotechnol 79:1043-1049. https://doi. org/10.1002/jctb. 1072

Anaerobic Treatment of Municipal Wastewater in UASB-reactors (2001) Technical Information W6e. Naturgerechte Technologien, Bau- und Wirtschaftsberatung (TBW) GmbH (ed)

Bal AS, Dhagat NN (2001) Upflow anaerobic sludge blanket reactor-a review. Indian J Environ Health 43(2):1-82

Baumgarten G, Sayfried CF (1996) Experiences and new developments in biological pre-treatment and physical post-treatment of landfill leachate. Water Sci Technol 34:445-453. https://doi. org/10.1016/S0273-1223(96)00777-9

Bodzek M, Łobos-Moysa E, Zamorowska M (2006) Removal of organic compounds from municipal landfill leachate in membrane bioreactor. Desalination 198:16-23. https://doi. org/10.1016/j.desal.2006.09.004

Bohdziewicz J, Kwarciak A (2008) The application of hybrid system UASB reactor-RO in landfill leachate treatment. Desalination 222(1-3):128-134. https://doi.org/10.1016/j.desal.2007.01.137

Bohdziewicz J, Neczaj E, Kwarciak A (2008) Landfill leachate treatment by means of anaerobic membrane bioreactor. Desalination 221:559-565. https://doi.org/10.1016/j.desal .2007 .01 .117

Calli B, Mertoglu B, Roest K, Inanc B (2006) Comparison of Long-term performances and final microbial compositions of anaerobic reactors treating landfill leachate. Bioresour Technol 97(4):641-647. https://doi.org/10.1016/j.biortech.2005.03.021

Castillo E, Vergara M, Moreno Y (2007) Landfill leachate treatment using a rotating biological contactor and an upward-flow anaerobic sludge bed reactor. Waste Manage 27:720-726. https ://doi.org/10.1016/j.wasman.2006.08.003

Chaundhari RJ, Basheer F, Farooqi IH (2008) Combined treatment of landfill leachate and domestic wastewater in submerged aerobic fixed film (SAFF) reactor. Asian J Water Environ Pollut 5:97-101

Chianese A, Ranauro R, Verdone R (1999) Treatment of landfill leachate by reverse osmosis. Water Res 33:647-652. https://doi. org/10.1016/S0043-1354(98)00240-1

Chiemchaisri C, Chiemchaisri P, Nindee W, Chang CY, Yamamoto K (2011) Treatment performance and microbial characteristics in two-stage membrane bioreactor applied to partially stabilized leachate. Water Sci Technol 64:1064-1072. https://doi. org/10.2166/wst.2011.534

Chiu Y-C, Chung M-S (2003) Determination of optimal COD/nitrate ratio for biological denitrification. Int Biodeterior Biodegrad 51:43-49. https://doi.org/10.1016/S0964-8305(02)00074-4

Cicek N (2003) A review of membrane bioreactors and their potential application in the treatment of agricultural wastewater. Can Biosyst Eng 45:637-649. https://doi.org/10.4236/jep.2015.66053

Cicek N, Dionysiou D, Suidan MT, Ginestet P, Audic JM (1999) Performance deterioration and structural changes of a ceramic membrane bioreactor due to inorganic abrasion. J Mebrane Sci 168(1):19-28. https://doi.org/10.1016/S0376-7388(99)00149-010

Cortez S, Teixeira P, Oliveira R, Mota M (2011) Denitrification of a landfill leachate with high nitrate concentration in an anoxic rotating biological contactor. Biodegradation 22:661-671. https ://doi.org/10.1007/s10532-010-9439-8

Crini G, Lichtfouse E (2018) Advantages and disadvantages of techniques used for wastewater treatment. Environ Chem Lett. https ://doi.org/10.1007/s10311-018-0785-9
Crites R, Tchobanoglous G (1998) Small and decentralized wastewater management systems. The McGraw-Hill Companies Inc, New York

Cui ZF, Chang S, Fane AG (2003) The use of gas bubbling to enhance membrane processes. J Membr Sci 221(1-2):1-35. https://doi.org/10.1016/S0376-7388(03)00246-1

Dydo P, Turek M, Ciba J, Trojanowska J, Kluczka J (2005) Boron removal from landfill leachate by means of nanofiltration and reverse osmosis. Desalination 185:131-137. https://doi. org/10.1016/j.desal.2005.03.076

Eckenfelder WW, Musterman JL (1995) Activated sludge treatment of industrial wastewater. Chapter 2: Characterization and pretreatment of industrial wastewater. Technomic, Lancaster, Basel

Foo KY, Hameed BH (2009) An overview of landfill leachate treatment via activated carbon adsorption process. J Hazard Mater 171:54-60. https://doi.org/10.1016/j.jhazmat.2009.06.038

Geenens D, Bixio B, Thoeye C (2000) Combined ozone-activated sludge treatment of landfill leachates. Water Sci Technol 44:359_ 365. https://doi.org/10.2166/wst.2001.0790

Geradi MH (2002) Nitrification and denitrification in the activated sludge process. J. Wiley, New York

Hasar H, Unsal SA, Ipek U, Karatas S, Cınar O, Yaman C, Kınacı C (2009) Stripping/flocculation/membrane bioreactor/reverse osmosis treatment of municipal landfill leachate. J Hazard Mater 17:309-317. https://doi.org/10.1016/j.jhazmat.2009.06.003

Henderson JP, Atwater JW (1995) High ammonia landfill leachate treatment using anaerobic filter and rotating biological contactor. Can. J. Civ. Eng. 22(5):992-1000. https://doi.org/10.1139/195-115

Hochheimer JN, Wheton FW (1998) Biological filters: trickling and RBC design. In: Libey GS, Timmons MB (eds) Proceedings of the second international conference on recirculating aquaculture roanoke. Virginia, pp 291-318

Im J-H, Woo H-J, Choi M-W, Han KB, Kim Ch-W (2001) Simultaneous organic and nitrogen removal from municipal landfill leachate using an anaerobic-aerobic system. Water Res 35(10):2403-2410. https://doi.org/10.1016/S0043-1354(00)00519-4

Jans JM, Schroeff AVD, Jaap A (1992) Combination of UASB pretreatment and reverse osmosis. In: Christensen, Cossu, Stegmann (eds) Landfill of waste: leachate. Elsevier Science Publishers Ltd. England. ISBN: 1-85-166733-4: 313-321

Judd S (2006) The MBR book. Principles and applications of membrane bioreactors in water and wastewater treatment. Elsevier, Oxford. ISBN: 1-85-617481-6

Kamaruddin MA, Yosoff MS, Aziz HA, Basri NK (2013) Removal of COD, ammoniacal nitrogen and colour from stabilized landfill leachate by anaerobic organism. Appl Water Sci 10:1-12. https:// doi.org/10.10007/s13201-013-0086-1

Keenan RJ, Iza J, Switzenbaum MS (1991) Leachate treatment with a pilot-scale, hybrid upflow anaerobic sludge bed filter reactor, emphasizing inorganic solid development. In: Proceedings 46th industrial waste conference, Purdue University, USA, pp 773-782

Kennedy KJ, Lentz EM (2000) Treatment of landfill leachate using sequencing batch and continuous flow upflow anaerobic sludge blanket (UASB) reactors. Water Res 34(14):3640-3656. https:// doi.org/10.1016/S0043-1354(00)00114-7

Kettunen RH, Rintala JA (1998) Performance of an on site UASB reactor treating leachate at low temperature. Water Res 32:537-546. https://doi.org/10.1016/S0043-1354(97)00319-9

Khan AI, Gaur RZ, Diamantis V, Lew B, Mehrotra I, Kazmi AA (2013) Continuous fill intermittent decant type sequencing batch reactor application to upgrade the UASB treated sewage. Bioprocess Biosyst Eng 36:627-634. https://doi.org/10.1007/s00449-012-0831-0 
Kiely G (1997) Environmental Engineering. McGraw-Hill international editions: chemical and petroleum engineering series. McGraw-Hill, London

Kim D, Ahn DH, Li DI (2005) Effects of free ammonia and dissolved oxygen on nitrification and nitrite accumulation in a biofilm airlift reactor. Korean J Chem Eng 22:85-90. https://doi.org/10.1016/ biortech.2005.03.032

Kjeldsen P, Barlaz MA, Rooker AP, Baun A, Ledin A, Christensen TH (2002) Present and long-term composition of MSW landfill leachate: a review. Crit Rev Environ Sci Tec 32(4):297-336. https ://doi.org/10.1080/10643380290813462

Kulikowska D, Klimiuk E (2008) The effect of landfill age on municipal leachate composition. Bioresour Technol 99:5981-5985. https ://doi.org/10.1016/j.biortech.2007.10.015

Kurniawan TA, Lo WH, Chan GYS (2006) Physico-chemical treatments for removal of recalcitrant contaminants from landfill leachate. J Hazard Mater B129:80-100. https://doi.org/10.1016/j. jhazmat.2005.08.010

Li Y-Y, Herbert HP, Fang TC, Chui H-K (1995) UASB treatment of wastewater containing concentrated benzonate. J Environ Eng 121(10):748-751

Li F, Wichmann K, Heine W (2009) Treatment of methanogenic landfill leachate with thin open channel reverse osmosis membrane modules. Waste Manage 29:960-964. https://doi.org/10.1016/j. jhazmat.2005.08.010

Liu Y, Li X, Wang B, Liu S (2008) Performance of landfill leachate treatment system with disc-tube reverse osmosis unit. Front Environ Sci Eng China 2(1):24-31. https://doi.org/10.1007/s1178 3-008-0024-x

Martienssen M, Schops R (1997) Biological treatment of leachate from solid waste landfill sites-alterations in the bacterial community during the denitrification process. Water Res 31(5):1164-1170

$\mathrm{Ng}$ ANL, Kim AS (2007) A mini-review of modeling studies on membrane bioreactor (MBR) treatment for municipal wastewaters. Desalination 212:261-281. https://doi.org/10.1016/j.desal .2006 .10 .013

Parkes SD, Jolley DF, Wilson SR (2007) Inorganic nitrogen transformations in the treatment of landfill leachate with a high ammonium load: a case study. Environ Monit Assess 124:51-56. https ://doi.org/10.1007/s10661-006-9208-7

Pasalari H, Farzadkia M, Gholami M, Emamjomeh MM (2018) Management of landfill leachate in Iran: valorization, characteristics, and environmental approaches. Environ Chem Letter 4:51-61. https://doi.org/10.1007/s10311-018-0804-x

Patsios SI, Karabelas AJ (2011) An investigation of the long-term filtration performance of a membrane bioreactor (MBR): the role of specific organic fraction. J Membr Sci 372(1-2):102-115. https:// doi.org/10.1016/j.memsci.2011.01.055

Pearce GK (2008) Introduction to membranes: an introduction to membrane bioreactors. Filtr Sep 45(1):32-35. https://doi.org/10.1016/ S0015-1882(08)70028-4

Renou S, Givaudan JG, Dirassouyan F, Moulin P (2008) Landfill leachate treatment: review and opportunity. J Hazard Material 150(3):468-493. https://doi.org/10.1016/j.jhazmat.2007.09.077

Richards LA, Vuachĕ C, Schäfer A (2010) Impact of pH on the removal fluoride, nitrate and boron by nanofiltration/reverse osmosis. Desalination 261:331-337. https://doi.org/10.1016/j.desal.2010.06.025

Robinson AH (2005) Landfill leachate treatment. Membrane Technol 6:6-12. https://doi.org/10.1016/S0958-2118(05)70435-3

Setiadi T, Fairus S (2003) Hazardous waste landfill leachate treatment using an activated sludge-membrane system. Water Sci Technol 48(8):111-117. https://doi.org/10.2166/wst.2003.0459

Shou-liang H, Bei-dou X, Hai-chan Y, Shi-lei F, Jing S, Hong-liang L (2008) In situ simultaneous organics and nitrogen removal from recycled landfill leachate using an anaerobic-aerobic process. Biores Technol 99:6456-6463. https://doi.org/10.1016/j.biort ech.2007.11.047

Singh V, Mittal AK (2012) Toxicity and treatability of leachate: application of UASB reactor for leachate treatment from Okhla landfill, New Delhi. Water Sci Technol 65(10):1887-1894. https://doi. org/10.2166/wst.2012.864

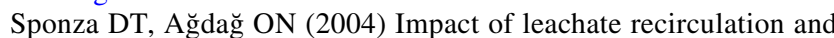
recirculation volume on stabilization of municipal solid wastes in simulated anaerobic bioreactors. Process Biochem 39:2157-2165. https://doi.org/10.1016/j.procbio.2003.11.012

Stegmann R, Heyer KU, Cossu R (2005) Leachate treatment. Proceedings Tenth International Waste Management and Landfill Symposium. Cagliari, Italy

Tatsi AA, Zouboulis AI (2002) A field investigation of the quantity and quality of leachate from a municipal solid waste landfill in Mediterranean climate (Thesaloniki, Grece). Adv Environ Res 6:207-219. https://doi.org/10.1016/S1093-0191(01)00052-1

Technology Options for Urban Sanitation in India (2008) A guide to decision-making. Pdf presentation. Washington: Water and Sanitation Program

The Attached Growth Process-An old technology takes on new forms 2004 (Pipeline, 1/15). Morgantown: National Small Flows Clearinghouse

Theepharaksapan S, Chiemchaisri C, Chiemchairi W, Yamamoto K (2011) Removal of pollutants and reduction of bio-toxicity in a full scale chemical coagulation and reverse osmosis leachate treatment system. Bioresour Technol 102:5381-5388. https://doi. org/10.1016/j.biortech.2010.11.091

Torabian A, Hassani AH, Moshirvaziri S (2004) Physicochemical and biological treatability studies of urban solid waste leachate. Int J Environ Sci Technol 1(2):103-107. https://doi.org/10.1007/BF033 25822

Trebouet D, Schlumpf JP, Jaouen P, Quemeneur F (2001) Stabilized landfill leachate treatment by combined physicochemical-nanofiltration processes. Water Res 35(12):2935-2942. https://doi. org/10.1016/S0043-1354(01)00005-7

Ushikoshi K, Kobayasahi T, Uematsu K, Toji A, Kojima D, Matsumoto K (2002) Leachate treatment by the reverse osmosis system. Desalination 150:121-129. https://doi.org/10.1016/S0011 $-9164(02) 00937-2$

Uygur A, Kargi F (2004) Biological nutrient removal from pretreated landfill leachate in a sequence batch reactor. J Environ Manage 71(1):9-14. https://doi.org/10.1016/j.jenvman.2004.01.002

Vicevic GP, Top PJ, Laughlin RGW (2005) Aerobic and anaerobic fixed film biological reactors. In: Christensen TH, Cossu R, Stegmann R (eds) Landfilling of waste: leachate. Taylor and Francis, Routledge

Visvanathan C, Choudhary MK, Montalbo MT, Jegatheesan V (2007) Landfill leachate treatment using thermophilic membrane bioreactor. Desalination 204:8-16. https://doi.org/10.1016/j.desal .2006 .02 .028

Voronova V, Moora H, Loigu E (2011) Environmental assessment and sustainable management options of leachate and landfill gas treatment in Estonian municipal waste landfills. Manag Environ Q Int J 22(6):787-802. https://doi.org/10.1108/14777831111170876

Wang Z, Wu Z, Yin X, Tian L (2008) Membrane fouling in a submerged membrane bioreactor (MBR) under sub-critical flux operation: membrane foulant and gel layer characterization. J Membrane Sci 325(1):238-244. https://doi.org/10.1016/j.memsc i.2008.07.035

Wend CF, Steward PS, Jones W, Camper A (2003) Pretreatment for membrane water treatment systems: a laboratory study. Water Res 37:3367-3378. https://doi.org/10.1016/S0043-1354(03)00234-3 
Wiszniowski J, Robert D, Surmacz-Górska J, Miksch K, Weber JV (2006) Landfill leachate treatment methods: a review. Environ Chem Lett 4:51-61. https://doi.org/10.1007/s10311-005-0016-Z

Zhang SJ, Peng YZ, Wang SY, Zheng SW, Guo J (2007) Organic matter and concentrated nitrogen removal by shortcut nitrification and denitrification from mature municipal landfill leachate. J Environ Sci 19(6):647-651. https://doi.org/10.1016/S1001-0742(07)60108 $-9$
Zolfaghari M, Drogui P, Brar SK, Buelna G, Dube R (2017) Unwanted metals and hydrophobic contaminants in bioreactor effluents are associated with the presence of humic substances. Environ Chem Lett 15(3):489-494. https://doi.org/10.1007/s10311-016-0598-7

Publisher's Note Springer Nature remains neutral with regard to jurisdictional claims in published maps and institutional affiliations. 